\title{
MODIFIKASI ALAT BANTU PEMBELAJARAN MELEMPAR DAN MENANGKAP DALAM HASIL BELAJAR PERMAINAN SOFTBALL
}

\author{
Aser Paul Nainggolan \\ Universitas Quality Berastagi, email : aserpaul@yahoo.co.id \\ Rizki Bastanta B. Manalu \\ Universitas Quality Berastagi, email : bastanta.rizki@gmail.com
}

\begin{abstract}
Abstrak
Permasalahan dalam penelitian ini adalah (1) pembelajaran gerak dasar melempar dan menangkap belum berjalan dengan maksimal, 2) Hampir sebagian besar siswa merasa kurang percaya diri, 3) Media pembelajaran yang digunakan oleh guru sesungguhnya kurang variatif, 4) Sarana dan prasarana sekolah yang memadai untuk mengembangkan model pembelajaran. Tujuan umum dari penelitian ini adalah untuk meningkatkan hasil siswa melalui model pembelajaran softball dengan menggunakan alat bantu modifikasi. Selain itu, penelitian ini dilakukan untuk mendapatkan informasi mendalam tentang penerapan permainan softball menggunakan pendekatan alat modifikasi. Penelitian ini merupakan penelitian tindakan dan objek pada penelitian adalah seluruh peserta didik kelas Siswa kelas VII di SMP Cahaya Pengharapan Abadi, yang berjumlah 32 peserta didik. Teknik pengumpulan data digunakan adalah tes, observasi dan dokumentasi. Penelitian ini dilakukan di tiga siklus. Berdasarkan hasil tersebut dapat disimpulkan bahwa modifikasi alat bantu pembelajaran melempar dan menangkap mampu meningkatkan hasil belajar siswa kelas VII SMP Cahaya Pengharapan Abadi sebesar 14 siswa (44\%) yang tuntas. Sedangkan jika dilihat dari siswa yang belum belum tuntas pada siklus II sebanyak hanya tersisa sebesar 5 siswa (15.63\%) belum tuntas jika dibandingkan dengan siklus I yaitu sebanyak 18 siswa (56\%) yang belum tuntas mampu menerapkan permainan melempar dan menangkap softball. Sehingga disimpulkan bahwa pada siklus II nilai ketuntasan sebesar $84 \%$.
\end{abstract}

Kata kunci: Modifikasi Alat Bantu, Hasil Belajar, Softball

\begin{abstract}
The problems in this study are (1) the basic motion learning of throwing and catching has not run optimally, 2) Almost the majority of students feel less confident, 3) The learning media used by teachers are actually less varied, 4) Adequate school facilities and infrastructure to develop learning models. The general objective of this study is to improve student outcomes through the softball learning model by using modification tools. In addition, this research was conducted to obtain in-depth information about the application of softball games using a modification tool approach. This research was an action research and the object of the study was all students of class VII students in Cahaya Harapan Harapan Middle School, which amounted to 32 students. Data collection techniques used were tests, observations and documentation. This research was conducted in three cycles. Based on these results it can be concluded that the modification of the throwing and catching learning aids can improve the learning outcomes of Grade VII students of SMP Cahaya Harapan Abadi Abadi by 14 students (44\%) who complete. Whereas if seen from students who have not yet completed in cycle II, there are only 5 students remaining (15.63\%) unfinished compared to cycle I, as many as 18 students (56\%) who have not been able to implement the game
\end{abstract}


throwing and catching softball. So it was concluded that in the second cycle the completeness value was $84 \%$.

Keywords: Modification of Tools, Learning Outcomes, Softball

\section{PENDAHULUAN}

Pendidikan jasmani adalah suatu bidang pendidikan dalam aktivitasnya lebih banyak menggunakan aktivitas fisik untuk menghasilkan perubahan holistik dalam kualitas individu, baik dalam hal fisik, mental, serta emosional. Pendidikan jasmani yaitu suatu bidang kajian yang berhubungan dengan aktivitas gerak manusia, perkembangan fisik dan psikis (Hartono, dkk. 2013: 2).

Belajar yaitu suatu proses terjadinya perubahan perilaku seorang siswa untuk dapat kearah yang cenderung lebih baik dari sebelumnya. Para siswa memerlukan stimulus atau rangsangan dari lingkungan untuk menghasilkan proses belajar bagi siswa sampai pada potensi maksimal gerak mereka. Misalnya siswa tidak mengetahui suatu kegiatan bersifat pengetahuan diharapkan dengan belajar siswa dapat lebih mengetahui dari yang tidak tahu menjadi tahu. Seperti pernyataan sudjana (2012:2) bahwa: Belajar sebagai suatu proses yang ditandai dengan adanya perubahan diri seseorang, perubahan yang dimaksud berupa hasil proses belajar dalam berbagai bentuk seperti terjadinya perubahan dalam pengetahuan, pemahaman, kecakapan, sikap dan tingkah laku, keterampilan, kebiasaan, serta perubahan lainnya.

Dalam ruang lingkup penjas terdapat point tentang permainan bola kecil diantaranya: kasti, bola bakar, rounders dan softball. Sekarang ini olahraga Softball adalah olahraga yang mulai digemari khususnya bagi anak muda, olahraga ini dianggap sebagai olahraga yang menyenangkan dan menyehatkan bagi yang melakukannya. Olahraga ini dianggap menarik karena memiliki cara permainan dan seragam yang dianggap unik berbeda dengan olahraga yang lainnya. Disekolah sendiri softball sudah menjadi mata pelajaran yang diwajibkan untuk diberikan kepada peserta didik karena softball sekarang sudah termasuk kepada permainan bola kecil yang dimana sudah dicantumkan dalam kurikulum.

Permainan bola softball atau lebih mirip seperti pada permainan kasti adalah olahraga permainan beregu yang dimainkan oleh 9 orang pemain dan bermain dalam 7 inning, yaitu masingmasing regu mendapat giliran menjadi pemain bertahan dan menyerang masingmasing 7 kali. Pergantian ini apabila regu bertahan berhasil mematikan pemain dari regu penyerang sebanyak 3 orang. Dalam kurikulum dijelaskan bahwa pencapaian indikator penilaian pada siswa kelas VIII adalah penguasaan teknik melempar, menamngkap dan memukul bola softball (Putri dan Ismiyati, 2016).

Modifikasi adalah sebuah cara untuk mempermudah pembelajaran apabilaalat yang dibutuhkan tidak dimiliki. Seperti kita sudah ketahui tidak setiap sekolah memiliki alat dalam kegiatan pembelajaran penjas maka dari itu disini dituntutlah kreatifitas seorang guru untuk dapat memodifikasi sebuah alat agar pembelajaran penjas yang diharapkan tetap tercapai dengan alat di modifikasi secara sederhana. Menurut Rizqi (2016) bahwa,"Modifikasi dapat diartikan upaya untuk menjadikan suatu perubahan dengan cara penyesuaian baik dalam segi fisik, fasiltas yang bertujuan dan cara (metoda, gaya, pendekatan, aturan, serta penilaian". 
Ada beberapa bentuk media dan bentuk model pembelajaran yang dapat digunakan dalam pembelajaran keterampilan memukul pada permainan softball, diantaranya dengan menggunakan alat bantu seperti batting $t$, soft toss, drop ball dan pitching mesin. Seperti yang sudah dikemukakan oleh Hamalik (2009:19) mengemukakan bahwa, alat bantu difungsikan sebagai alat untuk membantu individu dalam aktivitasnya, sehingga segala kegiatan yang dijalankan dapat efektif dan efisien. Maka dari itu mengapa di perlukannya alat bantu dalam memukul karna memukul adalah bagian yang sangat terpenting dalam permainan softball untuk dapat meraih kemenangan. Sepertiyang sudah dijelaskan oleh Suparlan dkk (2008:41) yaitu, "Memukul adalah bagian terpenting yang ada dalam permainan softball karena memukul dapat menentukan kemenangan suatu tim".

Dalam kegiatan pembelajaran softball peralatan yang digunakan sebagai media pembelajaran cenderung membutuhkan penyesuaian sesuai dengan tingkatan perkembangan peserta didik dan alat yang di miliki oleh sekolah dalam mencapai standar kompetensi yang diharapkan. Tetapi pada hasil observasi peneliti kenyataannya disekolah peralatan ini masih sangat minim dalam pengadaannya dan ruang lingkup yang kurang memadai. Dalam proses pembelajarannya sendiri sangatlah sulit dikarenakan jumlah siswa yang terlalu banyak dan waktu yang terbatas sehingga dapat menghambat proses belajar dan mengahambat pula terbentuknya keterampilan siswa dalam permainan bola softball, apalagi bagi sekolah yang akan dijadikan bahan penelitian bagi peneliti sekolah tersebut masih sangat jauh dari semua peralatan cabang olahraga softball bahkan meskipun sekarang dalam kurikulum, softball sudah dicantumkan sebagai mata pelajaran yang wajib pada kenyataan dilapangan mata pelajaran softball belum diajarkan yang dikarenakan oleh keterbatasan sarana, fasilitas dan tim pengajar yang kurang memahami olahrga softball.

Dalam hal ini penulis memilih salah satu alat bantu yang sudah dijelaskan diatas yaitu batting teeyang sudah dimodifikasi. Tujuan dari memodifikasi ini ingin menganalisis dan membuktikan sebuah pengaruh alat modifikasi terhadap keterampilan seseorang. Makadari itu berdasarkan uraian diatas peneliti mengambil sebuah judul penelitian yaitu modifikasi alat bantu pembelajaran melempar dan menangkap dalam hasil belajar permainan softball (studi action research pada siswa/i kls vii di SMP Cahaya Pengharapan Abadi).

\section{METODOLOGI PENELITIAN}

Penelitaan ini dilaksanakan di SMP Cahaya Pengharapan Abadi, pelaksanaan waktu penelitian pada tanggal Oktober 2019 sampai Desember 2019 dengan jumlah sampel 32 orang siswa/siswi kelas VII yang diambil dengan menggunakan teknik total sampling. Metode penelitian yang digunakan adalah metode Penelitian Tindakan (Action Research), dengan desain kemmis dan taggart (1988: 47) yaitu: "action reseach is cyclic process of planning, action, observation, and reflection", atau model yang berdasarkan pada suatu siklus spiral yang terdiri dari empat komponen, yang meliputi: (1) rencana tindakan (planning), pelaksanaan (action), (3) observasi (observation), (4) reflex (reflection). Penelitian tindakan merupakan salah satu bentuk rancangan penelitian, dimana dalam rancangan penelitian tindakan peneliti mendeskripsikan, menginterprestasikan dan menjelaskan suatu situasi sosial pada waktu yang bersamaan dengan melakukan perubahan 
atau intervensi dengan tujuan perbaikan atau partisipasi.

Pelaksanaan penelitian melibatkan rekan sejawat sebagai kolaborator dan guru kelas sebagai pelaksana tindakan. Hasil akhir dari kegiatan penelitian tindakan adalah meningkatkan hasil belajar khususnya pembelajaran pendidikan jasmani pada materi permainan softball siswa kelas VII SMP Cahaya Pengharapan Abadi.

\section{HASIL DAN PEMBAHASAN}

Penelitian action research ini dilakukan di sekolah Cahaya Pengharapan Abadi. Subyek penelitian pada penelitian tindakan kelas ini adalah siswa kelas VII. Jumlah siswa di kelas VII yang menjadi responden ini ada 32 siswa. Pelakasanaan penelitian tindakan kelas tentang hasil pembelajaran softball dengan modifikasi alat bantu melempar dan menangkap.

Pelaksanaan penelitian action research mengenai modifikasi alat bantu pembelajaran melempar dan menangkap dalam hasil belajar permainan softball dilakukan dalam 3 siklus yaitu pra siklus, siklus I, siklus II. Pertemuan pada penelitian ini dilakukan dalam waktu 4 jam kegiatan (4×35 menit) setiap kali siklus. Pelaksanaan kegiatan setiap siklus pada penelitian ini dapat dilihat pada tabel 1 .

Tabel 1. Pelaksanaan kegiatan penelitian Action Research

\begin{tabular}{c|c|c|c}
\hline No. & Siklus & Hari/Tanggal & Waktu \\
\hline 1 & $\begin{array}{c}\text { Pra } \\
\text { Siklus }\end{array}$ & $\begin{array}{c}\text { Selasa, 06 } \\
\text { Nopember 2019 }\end{array}$ & $07.30-11.00$ \\
\hline 2 & Siklus I & $\begin{array}{c}\text { Selasa, 13 } \\
\text { Nopember 2019 }\end{array}$ & $07.30-11.00$ \\
\hline 3 & Siklus II & $\begin{array}{c}\text { Selasa, 20 } \\
\text { Nopember 2019 }\end{array}$ & $07.30-11.00$ \\
\hline
\end{tabular}

\section{Data Pra Siklus}

Proses penelitian yang dilakukan untuk melihat hasil belajar permainan softball melalui kondisi awal dengan cara mengidentifikasi atau melakukan pengelompokan terlebih dahulu. Identifikasi atau pengelompokan tersebut pada kemampuan siswa dilhat dari penguasaan materi melempar dan menangkap sehingga dapat terlihat hasil dari permainan softball. Selanjutnya, setelah diperoleh data dari melempar dan menangkap maka dilakukan penyusunan rencana program berupa tindakan, observasi dan reflekasi.

Tahap awal yaitu observasi atau pengamatan awal peneliti merefleksikan bahwa siswa/siswi kelas VII di sekolah Cahaya Pengharapan Abadi memiliki beragam latar belakang seperti kemampuan motorik, postur tubuh, sikap, kebiasaaan dan motivasi yang berbeda dalam mengikuti kegiatan pembelajaran jasmani. Dari hasil pengamatan tersebut peneliti menjadi sedikit mengalami kesulitan. Hal ini dikarenakan peneliti harus melakukan pengelompokkan kemampuan dari siswa tersebut berdasarkan kemampuan melempar dan memukul softball.

Proses akhir, tindakan dan refleksi yang digunakan untuk mengetahui kekurangan penerapan program perencanaan yang muncul di analisis mengenai model pelajaran, pemberian materi, penerapan pendekatan bermain dan penggunaan modifikasi alat pembelajaran. Setelah terindentifikasi kekurangan dalam meningkatkan hasil belajar dengan pendekatan pola bermain dalam pembelajaran maka hasil identifikasi tersebut digunakan sebagai bahan untuk menyusun perencanaan berikutnya.

Setelah diketahui kondisi yang sebenarnya, maka peneliti akan melakukan tindak lanjut kegiatan yang harus dilakukan. Cara yang dilakukan peneliti yaitu dengan melakukan pendekatan terhadap siswa seperti bertanya kesulitan dibagian mana yang paling dirasakan oleh siswa, apakah pada saat memukul atau melempar softball. Dari hasil tersebut 
dicari pemecahan masalah agar siswa dapat menyenangi pembelajaran olahraga terutama softball.

Kegiatan pada pra siklus dilaksanakan pada selasa, 09 Nopember 2019 dengan jumlah siswa yang dijadikan objek pengamatan sebanyak 32 orang kelas VII, bertempat di sekolah Cahaya Pengharapan Abadi. Perolehan tingkat Keterampilan melempar dan menangkap permainan softball dapat dilihat sebagai gambar 1.

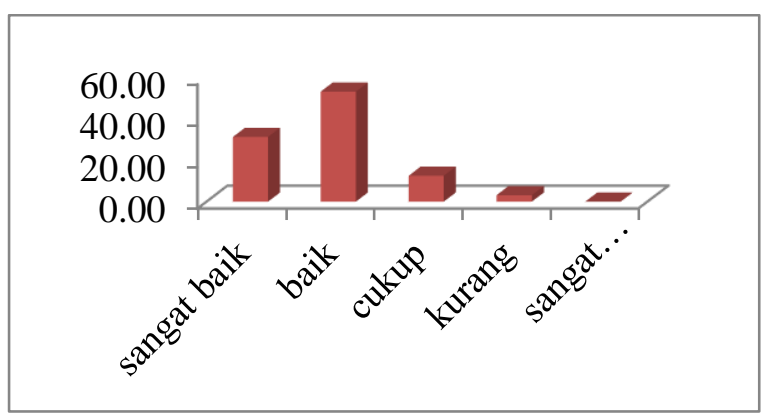

Gambar 1. Keterampilan melempar dan menangkap softball pada pra siklus

Hasil pra siklus penelitian diperoleh hasil bahwa kategori siswa sangat baik melempar dan menangkap permainan softball kategori baik sebanyak 5 siswa (15,63\%), kategori cukup sebanyak 8 siswa $(25,00 \%)$, kategori kurang sebanyak 12 siswa $(37,50 \%)$, kategori sangat kurang sebanyak 7 siswa $(21,88 \%)$. Sehingga dapat disimpulkan bahwa siswa kelas VII Cahaya Pengharapan Abadi mempunyai tingkat kemampuan melempar dan menangkap pada permainan softball termasuk dalam kelompok kurang dengan nilai pada kegiatan pra siklus dengan nilai rata-rata yaitu $52 \%$. Hasil penelitian pada modifikasi alat bantu melempar dan menangkat untuk memperoleh hasil belajar pada permainan softball hasil yang diperoleh nilai siswa sebanyak 5 orang $(15,63 \%)$ dalam kategori yaitu tuntas dan 27 siswa $(84,38 \%)$ yaitu belum tuntas dalam menyelesaikan kegiatan pada pra siklus pada gambar 2 .

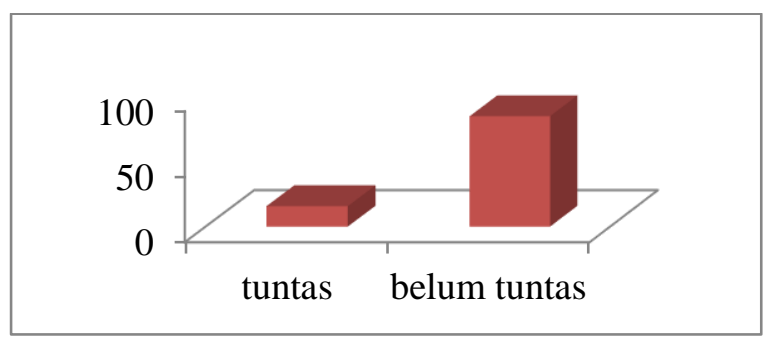

Gambar 2. Ketuntasan hasil permainan melempar dan menangkap pada Pra Siklus

\section{Siklus I}

Proses awal kegiatan data pada siklus I pada penelitian ini dilakukan di sekolah Cahaya Pengharapan Abadi. Awal kegiatan mula-mula setelah tanda bel masuk sekolah siswa menuju ke lapangan, selanjutnya guru akan memberikan arahan pada siswa mengenai kegiatan pelaksanaan penelitian yang dilakukan. Setelah memberikan penjelasan dan siswa tanya jawab, maka kegiatan tersebut dianggap dapat tercapai, artinya siswa telah dapat mengerti bagimana prosedur melempar dan menangkat softball yang akan dimulai. Selanjutnya akan dimulai kegiatan inti dari materi yang diberikan diawali dengan pemanasan tubuh terlebih dahulu.

Prosedur kegiatan inti (eksplorasi) diawali dengan demonstrasi yang dilakukan oleh guru terlebih dahulu, gunanya agar siswa dapat memahami bagaimana nantinya gerakan melempar dan menangkap yang dilakukan dapat benar. Tahap eksplorasi siwa diharapkan untuk dapat fokus dalam memperhatikan setiap gerak yang di praktekkan oleh guru tersebut. Prosedur elaborasi dilakukan dengan guru terlebih dahulu akan melakukan pembagian kelompok pada siswa. Pembelajaran awal diberikan dahulu dengan cara memberikan siswa kesempatan untuk melempar lempar bola di lapangan sesungguhnya. Kemudian setelah proses tersebut maka akan dilakukan proses kegiatan sebenarnya. 
Akhir kegiatan yaitu dengan pendinginan otot-otot tubuh. Kegiatan akhir ini dilakukan dengan bernyanyi memutar. Hasil melempar dan menangkap permainan softball siswa kelas VII sekolah Cahaya Pengharapan Abadi dapat dilihat pada gambar 3 .

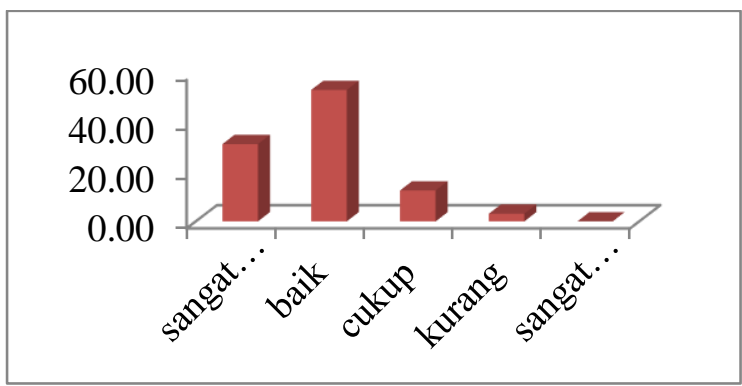

Gambar 3. Keterampilan Melempar dan Menangkap siklus I Softball

Gambar 3 menunjukkan hasil bahwa siswa kelas VII sekolah Cahaya Pengharapan Abadi dengan kategori sangat baik sebanyak 1 orang (3,13\%), kategori baik sebanyak 13 orang $(40,63 \%)$, kategori cukup sebanyak 15 orang $(46,88 \%)$, ketegori kurang sebanyak 2 orang $(6,25 \%)$ dan kategori sangat kurang yaitu 1 orang $(3,13 \%)$. Artinya siswa kelas VII Cahaya Pengharapan Abadi mempunyai tingkat keterampilan melempar dan menangkap kategori cukup dan nilai ratarata siklus I sebesar 57 . Metode bermain yang digunakan untuk melempar dan menangkap softball memberikan siswa gairah terhadap metode belajar yang menyenangkan, sehingga siswa dalam menjalankan tes yang dilakukan tidak mengenal kata menyerah walaupun hasil yang diperoleh tidak sesuai dengan standar yang dibuat. Sehingga jika minta untuk mengulangi gerakan melempar siswa tidak mengeluh.

Kemampuan melempar dan menangkap softball dengan modifikasi alat bantu mampu meningkatkan hasil belajar siswa pada siklus I dengan total nilai yang diperoleh sebanyak 18 siswa (56,25\%) dalam kategori belum tuntas dan 14 siswa
$(43,75 \%)$ tuntas. Berikut pada gambar 4 adalah tingkat ketuntasan siswa kelas VII Cahaya Pengharapan Abadi.

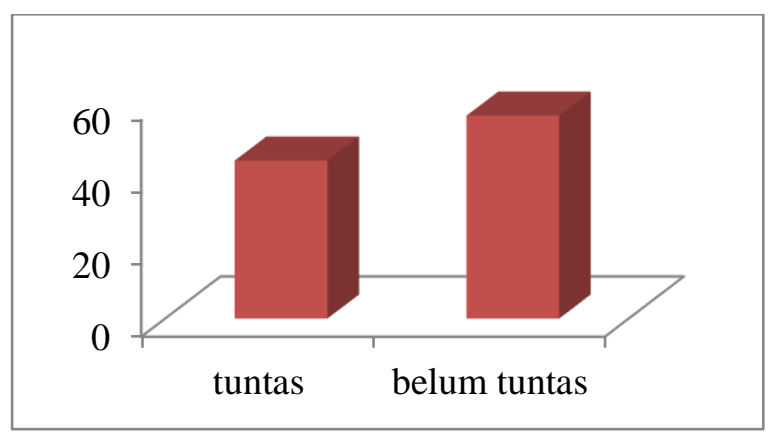

Gambar 4. Ketuntasan melempar dan menangkap softball siklus I

Untuk melihat keberhasilan setiap indikator, maka dilakukan perbandingan berdasarkan tingkat kategori yang dibuat yaitu kategori keberhasilan sebesar $75 \%$ pada tingkat ketuntasan. Adapun perbandingkan akan dibuat pada tabel 2 .

Tabel 2. Persentase perbandingan setiap siklus pada permainan softball

\begin{tabular}{c|c|c}
\hline Siklus & Belum Tuntas & Tuntas \\
\hline Pra & 27 & 5 \\
\hline $\mathrm{I}$ & 18 & 14 \\
\hline
\end{tabular}

Berdasarkan tabel 2, perbandingan tingkat ketuntasan siswa dalam permainan softball diperoleh hasil sebanyak 14 siswa (43,75\%) dapat dikatakan telah tuntas jika dibandingkan data pada nilai pra siklus, dimana hanya sebanyak 5 siswa (15,63\%). Pada pra siklus siswa kategori belum tuntas sebanyak sebanyak 27 siswa (84,38\%) mengalami penurunan jika dibandingkan dengan siklus I yaitu menurun menjadi 18 siswa (56,25\%). Berdasarkan hasil yang diperoleh, maka dapat disimpulkan bahwa terjadinya peningkatan sebesar $25 \%$ siklus I tetapi peningkatan tersebut belum mencapai pada indikator yang diharapkan peneliti yaitu $75 \%$ dapat perlu dilakukan tindak lanjut untuk peningkatan tersebut yaitu pada siklus II. 


\section{Siklus II}

Modifikasi alat bantu pada permainan softball memberikan semangat kepada siswa untuk melakukan kegiatan melempar dan menangkap bola. Hasil tes siklus II pada permainan softball pada siswa kelas VII sekolah Cahaya Pengharapan Abadi dapat dilihat pada gambar 5.

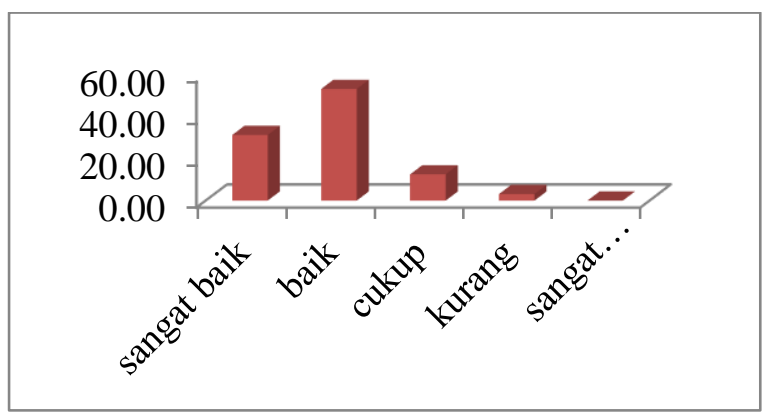

Gambar 5. Keterampilan Melempar dan

Menangkap pada Siklus II

Gambar 5 menunjukkan bahwa pada siklus II sebanyak 10 siswa (31,25\%) temasuk pada kategori sangat baik, 17 siswa (53,13\%) masuk dalam berkategori baik, 4 siswa $(12,50 \%)$ masuk dalam cukup, 1 siswa (3,13\%) pada kategori cukup. Sehingga dapat disimpulkan bahwa siswa kelas VII SMP Cahaya Pengharapan Abadi mempunyai tingkat Keterampilan melempar dan menangkap dengan kategori baik. Aidin dan Suroto (2016) menyatakan bahwa efektivitas pembelajaran dapat dilihat dari ketercapaian sasaran proses pembelajaran (efektivitas kemampuan guru mengelola pembelajaran dan aktivitas siswa) dan hasil pembelajaran (ketuntasan belajar). Efektivitas pembelajaran pada proses pembelajaran ada dua instrumen yang digunakan yaitu dari pendapat siswa (FCE) dan lembar observasi kelas dikjasor (kemampuan guru mengelola pembelajaran). Sedangkan dari segi hasil pembelajaran maka instrumen yang digunakan adalah penilaian hasil belajar lempar cakram. Sedangkan tingkat
Keterampilan melempar dan menangkap hasil diperoleh siswa secara keseluruhan sebanyak 27 siswa (84,38\%) dikatakan tuntas belajar dan 5 siswa $(15,63 \%)$ dikatakan belum tuntas belajar. Tingkat ketuntasan pada permainan softball dengan modifikasi alat bantu untuk meningkatkan hasil belajar siswa dapat dilihat pada gambar 6 berikut ini.

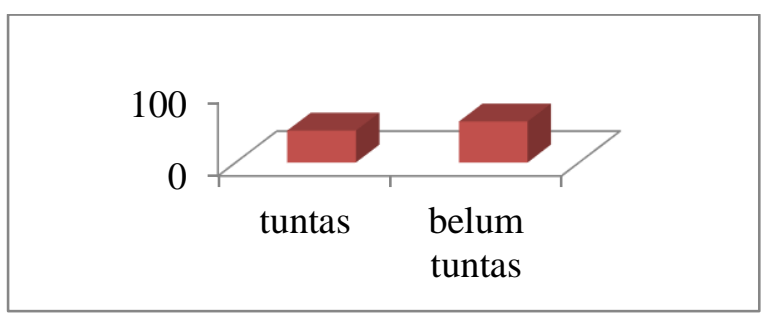

Gambar 6. Ketuntasan melempar dan menangkap pada Siklus II

Gambar 6 menunjukkan bahwa pada siklus II terjadi peningkatan jika dibandingkan dengan siklus I, dimana pada siklus II siswa yang belum tuntas sebanyak 5 orang $(15,63 \%)$, sedangkan telah tuntas sebanyak 27 siswa (84,38\%). Untuk perbandingan tingkat ketuntasan pada siklus I dan siklus II dapat dilihat pada gambar 7.

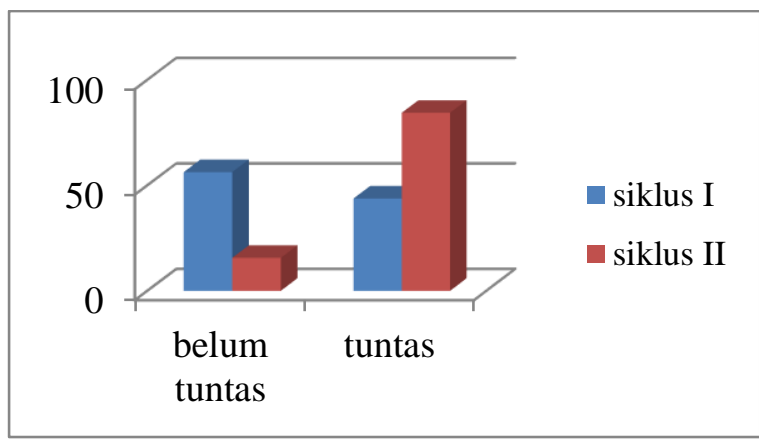

Gambar 7. Ketuntusan softball pada siklus II dan siklus I

Gambar 7, ketuntasan modifikasi alat bantu permainan softball untuk meningkatkan hasil belajar siswa diperoleh hasil sebanyak 27 siswa (84\%) dikatakan telah tuntas jika dibandingkan dengan nilai siklus I bahwa hanya 14 siswa (44\%), siklus II sebanyak 5 siswa (16\%) dikatakan 
belum tuntas. Jika dilihat hasil tersebut maka sudah dapat dikatakan terjadinya peningkatan sebesar $84 \%$ di siklus II.

Menurut peneliti dan kolaborator, peneliti berhenti sampai disini dan tidak melanjutkan ke siklus berikutnya, karena permasalahannya sudah terjawab yaitu melalui penelitian penerapan pola pendekatan bermain terhadap proses belajar mengajar.

Setelah selesai pengajaran selama siklus I dan siklus II, kolaborator mengutarakan hasil pengamatannya selama proses pembelajaran berlangsung pada peneliti, berupa angka-angka kuantitatif yang mungkin dibandingkan antara siklus dan siklus II. Untuk lebih jelasnya mengenai perncapaian hasil belajar gerakan antara siklus I dan siklus II dapat dilihat dalam perbandingan grafik sebagai berikut:

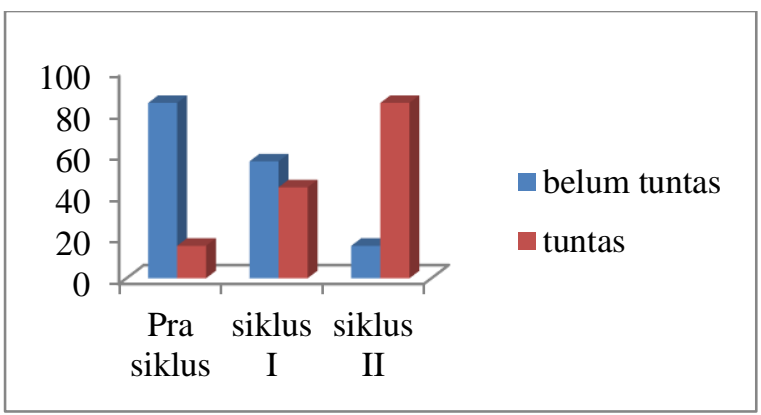

Gambar 8. Peningkatan hasil belajar siswa dalam permainan softball

Penelitian Prayoga (2016) bahwa pada penelitian yang dilakukan diketahui bahwa keberhasilan proses pembelajaran tergantung pada beberapa faktor. Faktorfaktor tersebut berasal dari pihak guru maupun siswa serta alat/media pembelajaran yang digunakan. Faktor dari pihak guru yaitu kemampuan guru dalam mengembangkan materi, kemampuan guru dalam menyampaikan materi, kemampuan guru dalam mengelola kelas, metode yang digunakan guru dalam proses pembelajaran, serta teknik yang digunakan guru sebagai sarana untuk menyampaikan materi. Sedangkan faktor dari siswa yaitu minat dan motivasi siswa dalam mengikuti proses pembelajaran.

\section{KESIMPULAN DAN SARAN Simpulan}

Berdasarkan hasil penelitian dilakukan maka dapat disimpulkan bahwa terdapat peningkatan hasil belajar siswa melalui pola pendekatan bermain pada pembelajaran pendidikan jasmani gerak melempar dan memukul permainan softball pada siswa kelas VIII SMP Cahaya Pengharapan Abadi. Hal ini dapat dibuktikan dengan bahwa siklus II sebanyak 27 siswa (84\%) dikatakan telah telah tuntas dalam permainan softball dengan menggunakan modifikasi alat bantu, jika dibandingkan hasil pada siklus I yaitu hanya sebesar 14 siswa (44\%) yang tuntas. Sedangkan jika dilihat dari siswa yang belum belum tuntas pada siklus II sebanyak hanya tersisa sebesar 5 siswa (15.63\%) belum tuntas jika dibandingkan dengan siklus I yaitu sebanyak 18 siswa (56\%) yang belum tuntas mampu menerapkan permainan melempar dan menangkap softball. Sehingga disimpulkan bahwa pada siklus II nilai ketuntasan sebesar $84 \%$.

\section{Saran}

Saran yang dapat diberikan pada penelitian ini adalah:

1. Penelitian lebih lanjut yaitu dengan melakukan penerapan modifikasi permainan softball yang dibuat lalu mengukur terhadap hasil belajar siswa.

2. Dalam memberikan modifikasi permainan softball, hendaknya memperhatikan model atau metode yang mampu membuat siswa lebih termotivasi dalam belajar pembelajaran. 


\section{DAFTAR PUSTAKA}

Hamalik, oemar., (2009), Proses Belajar Mengajar, penerbit PT bumi Aksara, Jakarta

Hartono, Soetanto, dkk. 2013. Pendidikan Jasmani (Sebuah Pengantar). Surabaya: Unesa University Press.

Kemmis dan Mc Taggart. 1988. The Action Research Planner Third edition.Victoria: Deakin University Press.

Putri N, Ismiyati. 2016. Meningkatkan Motivasi Gerak Dalam Permainan Bola Softball Dengan Modifikasi Alat Pada Siswa Kelas Viii Smp Muhammadiyah 2 Yogyakarta. Jurnal Pendidikan Jasmani Indonesia Volume 12, Nomor 1,11-15.

Prayoga AS. 2016. Upaya Meningkatkan Hasil Belajar Servis Bawah Bola Voli Melalui Penggunaan Modifikasi Bola. Jurnal Sportif, 2(1);1-12.

Rizqi R. 2016. Penerapan Modifikasi Permainan Softball Terhadap
Motivasi Belajar Siswa Dalam Pendidikan Jasmani, Olahraga Dan Kesehatan (Pada Siswa Kelas VII MTs. Assa'adah 1 Sampurnan Bungah Gresik). Jurnal Pendidikan Olahraga dan Kesehatan Volume 04 Nomor 02, $307-312$.

Sudjana, Nana. 2012. Penelitian Hasil Proses Belajar Mengajar. Bandung: Remaja Rosda Karya. 